Article received on $2^{\text {nd }}$ October 2012

Article accepted on $24^{\text {th }}$ October 2012

UDC: 78.037

\author{
Mirjana Veselinović-Hofman \\ University of Arts in Belgrade \\ Faculty of Music \\ Department of Musicologyć
}

\title{
THE NATURE OF POST-MODERN CLASSICALITY IN EUROPEAN MUSIC
}

\begin{abstract}
This text examines the difference between manifestations of the classical in post-modernism, considered in the broader sense of the word when hyphenated, and postmodernism in the narrower sense when written without the hyphen. The classical in postmodernism manifested itself in neoclassicism as a compositional-technical and aesthetic category, and in the form of postmodern classicality. A postmodern composition can reference classicality whenever it is based on the play of classical signifiers according to any of the possibilities examined in this article: 1) when classical/neoclassical musical materials 'respond' to classical procedural signifiers; 2) when classically referenced materials are subjected to non-classical procedures; 3) when non-classically referenced materials are subjected to classical procedures.
\end{abstract}

Keywords: post-modernism, neoclassicism, postmodern neoclassicism, postmodernism, postmodern classicality.

* Author contact information: mvesel@eunet.rs

** This research was finalized as part of the scientific project of the Department of Musicology, Faculty of Music in Belgrade, "Serbian music identities within a world cultural context", supported by the Ministry of Education and Science of the Republic of Serbia. 
Апстракт: У тексту се испитује разлика између манифестација класичног у посmмодернизму схваћеном у ширем смислу речи, када се пише са цртицом и постмодернизму, схваћеном у ужем смислу, када се пише без цртице. У постмодернизму се класичност манифестује у неокласицизму као композиционотехничкој и естетичкој категорији, али се манифестује и у форми постмодерне класичности. Постмодерна композиција упућује на класичност када год је базирана на игри класичних означитеља а према једној од могућих варијанти које се у раду испитују: 1) музички материјали класичних/неокласичних одлика 'слажу' се са класичним процедуралним означитељима; 2) материјали класичног карактера подвргнути су некласичним процедурама; 3) материјали некласичног карактера подвргнути су класичним процедурама.

Кључнеречи: пост-модернизам, неокласицизам, постмодерни неокласицизам, постмодернизам, постмодерна класичност.

The main thesis of this article is that the classical in contemporary, postmodern European music refers to a new kind of classicality quite distinct from returns to the classical in its usual guise as stylistic category. Postmodern classicality differs considerably from that which was 'stylistically legitimate' as classical in music up to and including 'neo'- styles. This difference derives from the fact that the notion of the classical has been changed not only by high modernism (represented by the avant-garde), but also through the process of the avantgarde's incorporation into tradition, which occurred during the early 1970s.

Absorbed by the particularities of its own methodological, technical and aesthetic rebellious undertakings, the avant-garde challenged the notion of style in general. Quite clearly, this agenda displayed no tolerance towards classical classicality. However, the avant-garde and tradition inevitably came to terms with each other. A 'truce' ensued in which the avant-garde acknowledged the tradition that it previously disowned, with the result that it became an extension of that very tradition. At this historical juncture, postmodernism was born, and with it also a new kind of classicality.

I should like to expand on this idea by elaborating the difference between manifestations of the classical in post-modernism, considered in the broader sense of the word when hyphenated, and postmodernism in the narrower sense when written without the hyphen. As is illustrated in Table 1, the broader meaning is chronological, and refers to the whole map of compositional paths in the period after high modernism. The narrower meaning is stylistic, and refers to a specific path within this map. ${ }^{1}$

\footnotetext{
${ }_{1}$ See more about this in my book Fragmente zur musikalischen Postmoderne. Frankfurt am Main: Peter Lang, 2003.
} 
Table 1: Meanings of the term post(-)modern(ism)

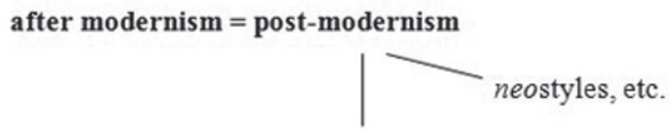

postmodernism

The classical in post-modernism manifested itself in neoclassicism as a technical and aesthetic category, but also in the form of postmodern classicality (see Table 2); a new, typically delineated strain of postmodernism as a homogeneous tendency within the stylistic plurality covered by the term post-modernism.

Table 2: Connections of the 'classical' with post-modernism

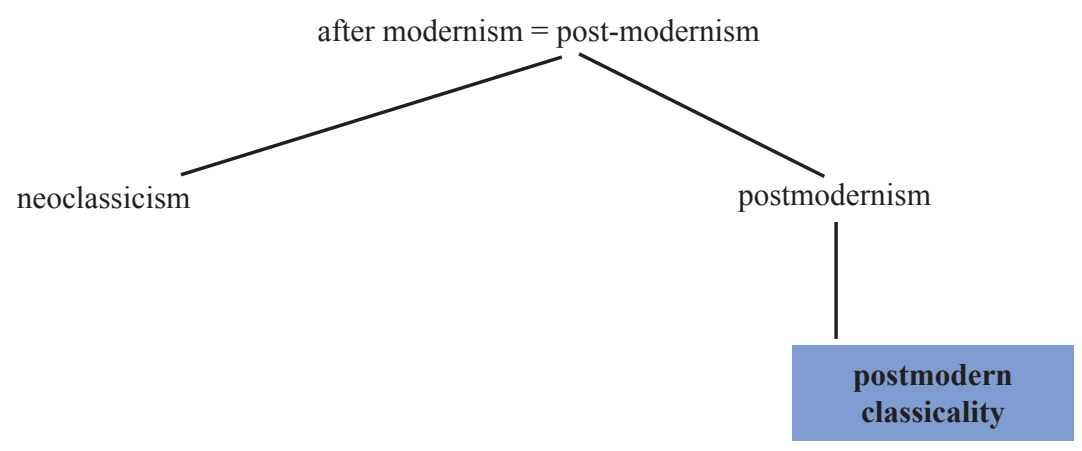

Viewed from within post-modernism, neoclassicismassumes a dual meaning defined by the motivation and direction from which it is approached. On the one hand, neoclassicism represents a 'way out' for the avant-garde, being a form of the avant-garde's own radical (self)-critique. Examples are Krzysztof Penderecki's Violin Concerto (1977), II Symphony (1980) or RajkoMaksimović's Knjiga madrigala, Iz tmine pojanje ('Book of Madrigals, The Chant from the Darkness')(1975) or his oratorio Buna protiv dahija ('The Rebellion against the Dahias') (1978). This means that the one point of entry into neoclassicism in the period after high modernism is from the avant-garde, and in this guise it is about a specific return to the neoclassical style. On the other hand, we know that neoclassicism was one of the most persistent styles existing in parallel with the avant-garde, its decay, and the challenges of the post-modern period. This 
suggests that a second entry into neoclassicism during this period leads from neoclassicism itself (see Table 3), which is why it does not refer to a return but to the continuance of neoclassicism.

Table 3: The continuance of neo-classicism

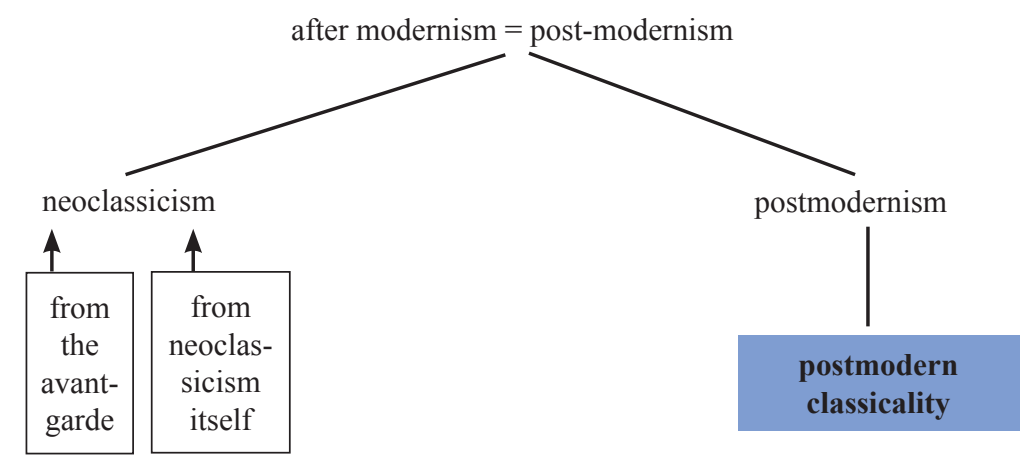

Seen from this perspective, music composed according to procedures characteristic of neoclassicism remains neoclassical in its aesthetic and technical motivation, origin and features. For this reason there is no sound basis for labelling the piece postmodern except in the broader, that is, post-modern or chronological sense. To be sure, both these theoretical positions of neoclassicism after modernism reference neoclassicism as an identifiable style. The only difference is that the first of these positions endows neoclassicism with a complex avantgarde history. This should not be understood to mean that neoclassicism is a static style only ever reproducing itself by the same means. In its progressive manifestations, neoclassicism has been subject to the dynamic forces of music. This kind of neoclassicism I should like to call developing neoclassicism. This neoclassicism has endured due to its absorbtion of various musical solutions created in other styles into its own aesthetic, stylistic norms. ${ }^{2}$ In other words, neoclassicism has appropriated these solutions, turning their features into the stylistically classical.

Moreover, composers consistently working within a neoclassical aesthetic, with scant regard for musical novelties, ${ }^{3}$ have selectively included in their works

\footnotetext{
2 For example at the level of harmony, rhythm, instrumental colour etc., characterizing Baroque music, Romanticism, Impressionism, Expressionism and even the avant-garde. ${ }^{3}$ Neoclassicists especially opposed the sound aggression of avant-garde musical achievements. In return, avant-garde composers looked down on neoclassical standpoints and compositional routine.
} 
not only avant-garde residues but also more recent postmodern methods of composing. Although these composers did not, as a rule, consider these novelties as something indispensable or necessary, but simply present hic etnunc, and therefore available to be used, a point was reached whereby neoclassicism closely approached postmodernism as a stylistic tendency and eventually merged with it. Psychologically, neoclassicists endorse this explanation as it provides clear proof of the demise of the avant-garde.

What is important to recognize here is that a genuine representative of neoclassical style can easily cross the boundary between neoclassicism and postmodernism. A composer, because of his developing neoclassicism (possibly also including elements of postmodern processes), can come to be seen as a representative of postmodernism as well. But importantly, the approach to postmodernism in such a composer is not the result of an essential change of aesthetic views. Spiritually, then, and to a considerable extent aesthetically, a composer like this remains a neoclassicist. Technically, neoclassical and postmodern substances are blended, thus traversing the fragile musical boundary between neoclassicism and postmodernism. Examples would be Maxwell Davies, Dejan Despić, Nancy van de Vate, and to an extent also Alfred Schnittke. Despite a variety, even predominance of postmodern elements in this merging process, the formal point of departure is usually consistently classical formal devices. And it is primarily because of these devices being present that a postmodernpiece could achieve a kind of 'transitional' level towards a particular postmodern classicality. I will call this level postmodern neoclassicism, and it is graphically illustrated in Table 4.

Table 4: Postmodern neoclassicism

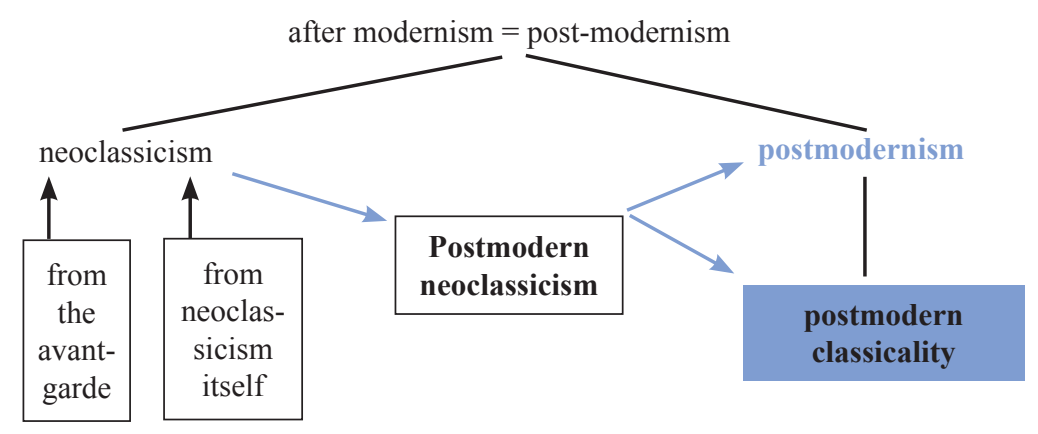

Methodologically and technically, postmodern neoclassicism therefore stands somewhere between the 'pure' neoclassicism practiced after modernity, 
presented above with regard to its two main positions, and postmodern classicality, which I will now proceed to discuss.

The essential difference between neoclassicism in all its guises and postmodern classicality, is that the latter does not include the stylistic revival of neoclassicism. Quite to the contrary, postmodern classicality is thoroughly rooted in typical postmodern poetics and compositional technology. One of the essential features of both poetics and technology stems from the specific focus of postmodern method on the phenomenon of the musical fact as such and on its communication potential. Put it other words, it stems from an interest in musical materials from the entire world heritage, without regard to stylistic, historical, geographical, ethnic or any other origin. Furthermore it also stems from a total creative freedom to select and combine these materials during the structuring of a piece of music, as well as from dispensing with the need to fulfil any recognizable stylistic requirements.It goes without saying that these materials do not exclude those belonging to classical or neoclassical musical discourses. The latter share the position and fate of other materials in postmodern compositions: they are deprived of their own stylistic contexts to become part of new contexts determined by the individual creative aims and processes of the author. This is clearly also a form of intertextuality, in which quoted material (from classical, folklore or jazz origin, to name but a few possibilities) acts in a dual way. First, as an acoustic means in itself, selected for those sound qualities that the composer finds appropriate to use as integral components of the work. Secondly, it acts as a means of communication, a symbol of the whole spectrum of possible musical and extra-musical meanings to which the musical source of the quotation might refer. In this second role, a quotation functions as a representative of its primary context. Material cited from a classical or neoclassical work or gesture has the same function: the material becomes a crucial site of signification. Based on the associative mechanism, according to the pars pro toto principle, such a quotation will always re-activate classicality. Whether it will do so directly (that is, reminding one of a specific composition from which the quotation is taken), or indirectly (evoking classicism in general), depends on the way in which the quotation is treated in the new composition.

Quoted material is more than a sample. It is also more than a carrier of static sound quality and more than a fixed signifier. In reality, quotations are generally subjected to various musical changes, which unavoidably affects their initially signified meanings. ${ }^{4}$ Any quotation (including from classical or neoclassical sources), can assume three forms. First, it can be a complete quotation of a musical fragment or sample, cut out in its totality from its source composition

\footnotetext{
${ }^{4}$ I wrote extensively about this problem in Fragmente zur musikalischen Postmoderne.
} 
and incorporated as such into a new compositional discourse. Secondly, it can be an incomplete quotation, meaning that recognition of a primary context depends on individual components (rhythmic, melodic, harmonic, etc.) being heard as signifiers of its original milieu. Thirdly, it can be a simulation of quotation. This means that musical material is created in such a way that it appears as a citation. We could call this the instance of the false sample.

In all three cases, quotations represent their real or imagined sources, which could include classical or neoclassical ones. And in all three cases, quotations act in their new contexts as signifiers of these sources and their latent musical and extra-musical meanings. And yet these quotations or samples are subjected to varied processes of development and change that could include modification or transformation of any musical component of the sample, or even of its inner acoustical features through electronic means. The changes can be so radical that neither the sample, nor its various manifestations created through these changes, can any longer be recognized as such. When this happens, the quotation actually leaves the level of signification referencing the specific source. A quotation will associate with its source (and its whole classical musical aura) as long as it can be recognized as material originating from this source. This remains true until development of the quotation reaches the stage when it loses all semblance of its original identity.

At this point, further levels of signification are activated, of which there are principally two possibilities. The first is that the quotation disappears completely through processes of musical development and change. It is transformed into many other entities that can act as further signifiers, even signifiers of musical and aesthetic milieus that essentially contrast with the initial, classical icon. A second possibility is that the sample is developed in such a way that it still recalls the signification field of the classical/neoclassical. By keeping within itself a faint but recognizable classical 'grain', the quotation sheds the role of signifying a specific classical/neoclassical composition and its context, and adopts more general classical signification. It is precisely this stage of signification that is accomplished predominantly at the level of compositional-technical processes and formal devices. To be more precise, technical and formal gestures and the constituent elements of such gestures assume the role of signifiers similar to that of quoted musical fragments. Naturally, the act of quotation is more tangible when it concerns musical particulars such as motives, rhythmic patterns or the like, than when it concerns compositional procedures (although these exist and act in a postmodern piece analogously to quotations of musical material). ${ }^{5}$

5 The problem of quotation as it relates to form, compositional technique and principles of instrumentation is discussed in more detail in ibid. 
The possibilities of choice and combination in a postmodern aesthetic are in principle limitless. With particular reference to the classical, this may involve process-phases represented by formal classical emblems, forms of thematic work typical of various developmental phases of classicism, or even characteristic classical textures. But it can also concern more indirect features connected with the aesthetic category of the classical. Possible examples include symmetry; the principle of horizontal and vertical addition of musical elements and their 'calm' coexistence within the musical unfolding (rather than the principle of development and conflict); objective rather than subjective time (that is, ontological rather than psychological time); 'music of being' rather than'music of becoming'. Generally, most of these features display a general Apollonian, rather than Dionysian, character and spirit. When a signifier reaches this level of signifying classicality, it performs the role of a non-palpable, floating signifier.

Of course, all this also implies complex relationships between musical particulars and elements of procedures employed in a postmodern aesthetic. Thus a composition can include many materials and procedural fragments, of which the classical/neoclassical features need not match, to obtain postmodern classicality.

Table 5: The relationship betweenpostmodern classicality and classical/neoclassical musical materials

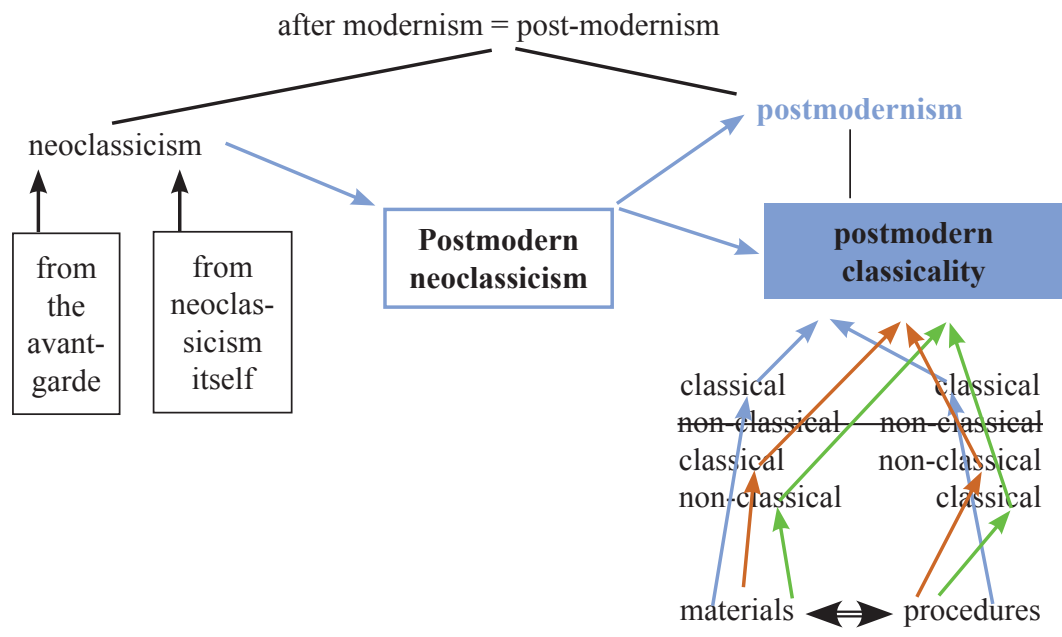

The instance of postmodern classicality in which classical/neoclassical musical materials 'respond' to classical procedural signifiers (see Table 5, in which the blue arrows refer to the box 'postmodern classicality'), is illustrated in, for 
Veselinović-Hofman, M.: The Nature of Post-Modern Classicality ... (49-57)

example, 'Valcer' ('The Valse') from the Koncertantna muzika ('Concertante Music') (1993) by Srđan Hofman or at the beginning of the Rondo from Alfred Schnittke's first Concerto grosso(1977). ${ }^{6}$ However, there are two more possible relationships between postmodern classicality and material. First, classically referenced materials can be subjected to non-classical procedures (Table 5, orange arrows), during which such materials can lose or retain their classical axis. An example of this is the beginning of the Prelude, or the transition from the Rondo to the Postludio in Schnittke's first Concerto grosso. A second possibility is when non-classically referenced materials are subjected to classical procedures (Table 5, green arrows). Examples of this are heard in Schnittke's first Concerto grosso and in the opening section of Zoran Erić's composition for strings entitled Helijum u maloj kutiji ('Helium in a Small Box') (1991). Either a classical or a non-classical character can prevail in both cases, depending on the classical strength of the signifiers. These signifiers and floating signifiers, be they musical contents or technical elements inhabiting quoted or developed forms, need to function clearly as classical signifiers in order to endow a composition with the character of postmodern classicality. To summarize, a postmodern composition can reference classicality whenever it is based on the play of classical signifiers according to any of the possibilities examined in this article.

\section{REFERENCES}

Adorno, Theodor W., "Klassik, Romantik, Neue Musik”, in: Adorno, Theodor W.: Musikalische Schriften I-III. Gesammelte Schriften,Band 16, Rolf Tiedemann (Hrsg.), Frankfurt am Main: Suhrkamp, 1978, 126-144.

"Contemporary Music and the Public - Michel Foucault and Pierre Boulez", in: John Rahn (ed.). Perspectives on Musical Aesthetics, New York - London: W. W. Norton \& Company, 1994, 83-89.

Kramer, Jonathan D.,"Beyond Unity: Toward an Understanding of Musical Postmodern", Concert Music, Rock, and Jazz since 1945: Essays and Analytical Studies, University of Rochester Press, 1995.

Klassizistische Moderne, Hrsg. Hermann Danuser, Winterthur: Amadeus, 1997.

Veselinović-Hofman, Mirjana, Fragmente zur musikalischen Postmoderne, Frankfurt am Main, etc.: Peter Lang, 2003.

${ }_{6}$ The other possibility is represented by the non-classical, a term that references a situation in which neither musical material nor technical components display classical/neoclassical traits. This possibility is not addressed in this article. 